Portland State University

PDXScholar

$5-14-1987$

\title{
The Effects of a Course in American Jokes on a Class of Intermediate Level ESL Students
}

John Randolph Carruthers

Portland State University

Follow this and additional works at: https://pdxscholar.library.pdx.edu/open_access_etds

Part of the English Language and Literature Commons, and the Language and Literacy Education Commons

Let us know how access to this document benefits you.

\section{Recommended Citation}

Carruthers, John Randolph, "The Effects of a Course in American Jokes on a Class of Intermediate Level ESL Students" (1987). Dissertations and Theses. Paper 3657.

https://doi.org/10.15760/etd.5539

This Thesis is brought to you for free and open access. It has been accepted for inclusion in Dissertations and Theses by an authorized administrator of PDXScholar. Please contact us if we can make this document more accessible: pdxscholar@pdx.edu. 
AN ABSTRACT OF THE THESIS OF John R. Carrutherg for the Master of Arts in English:TEsol presented May 14, 1987. Title: The Effects of a Course in Amerlcan Jokes on a Class of Intermediate Level EsL students. ARPROVED BY MEMBERS OF THE THESIS COMMITTEE:

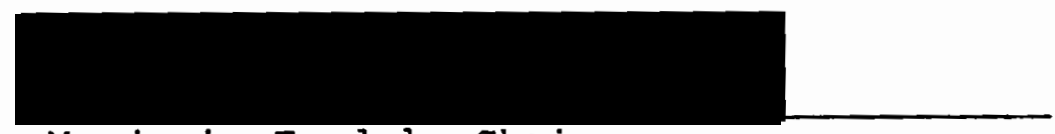
Marjorie Terdal, Chairperson
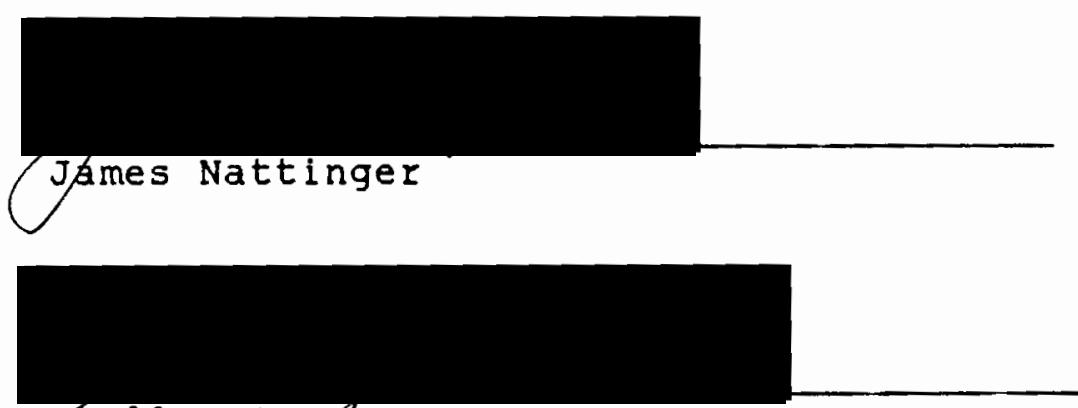
Shelley Reege

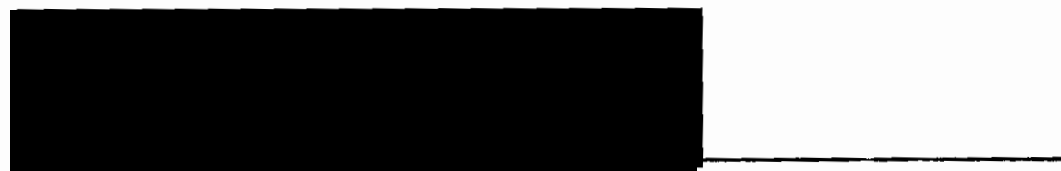

Einda walton

Teachers of English to speakers of other languages have often incorporated humor in the curriculum, yet a recent computer search revealed that there were no empirical studies which have shown that curricular humor enhances English language learning. The three specific questions of the thesis are: does the use of curricular 
humor 1) Improve memory/recall, 2) Improve over-all English proficiency, and 3) result in the subjects' having more positive attitudes towards Americans, and if so, does a more positive attitude correlate with 1 mproved memory/proflclency?

Data was obtained by testing an Experimental Group and a Control Group consisting of Level three (intermediate) international students enrolled in the Center for English as a second Language at Portland state University. The Experimental Group was exposed to a Elve week, twenty hour course in Amerlcan Jokes.

To measure memory/recall, a dictation test was administered before and after the humor course. Proflciency data was obtained from the subjects' precourse and post-course Michlgan Test of English Language Proflclency scores. Attltude data was gathered by means of a survey. The data was statistically analyzed for signiflcant differences and correlations between the Experimental and Control Groups.

The results reveal that it cannot be sald with certalnty that adding a short course in humor to a curriculum will result in increased memory/recall abllity, improved proflciency, more positive attltudes towards Americans, or that positive attitudes correlate with higher recall/proflciency scores. The attitude survey did reveal that the control Group had a 
signiflcantly more positive attitude toward Americans. There are several possible reasons that the influence of the humor course was minimaliy signiflcant: the jokes might not have been challenging enough to measure improvement; the technique of providing a schema of the structure of a joke may not have been effective for these subjects; the humor course may have been too short to be a signiflcant Influence; the Mlchigan Test of English Language Proficlency may be the wrong instrument to measure the effects of a humor course; lastly, the fact that only a post-course attitude survey was taken leaves open the possibility that the control Group had a more positive attitude before the humor course. 
THE EFFECTS OF A COURSE IN AMERICAN JOKES

ON A CLASS OF INTERMEDIATE LEVEL

ESL STUDENTS

\author{
by \\ JOHN RANDOLPH CARRUTHERS
}

A thesis submitted in partial fulfillment of the requirements for the degree of

\author{
MASTER OF ARTS \\ in \\ ENGL I SH : TESOL \\ Portland state UnIversity
}

1987 
TO THE OFFICE OF GRADUATE STUDIES AND RESEARCH:

The members of the committee approve the thesis of John R. Carruthers presented May 14, 1987.

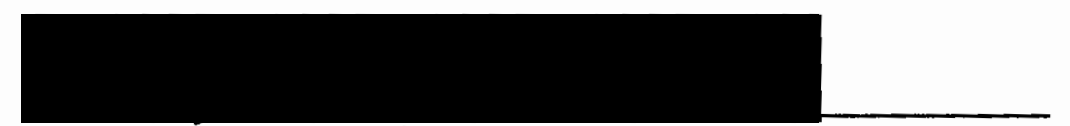

Marjorie Terdal, Chairperson

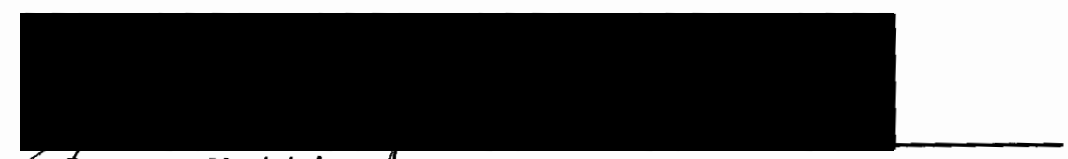

James Nattinger

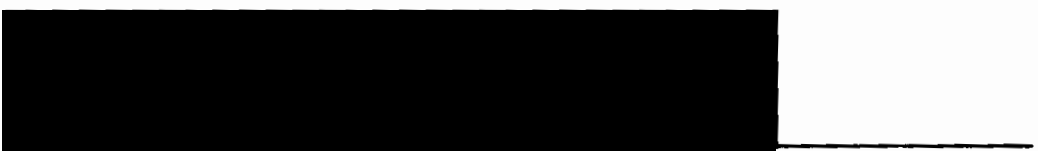

shelley Reege

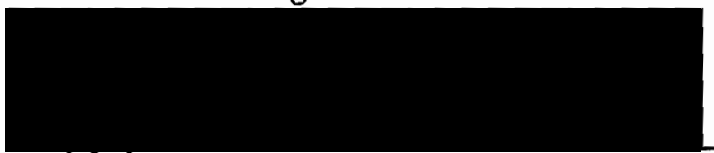

Linda walton

APPROVED :
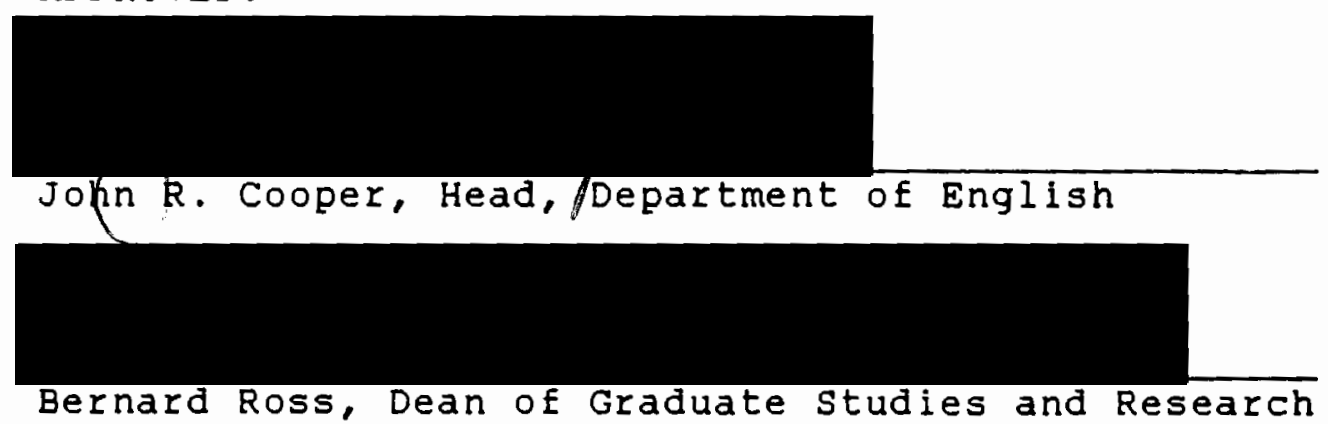


\section{ACKNOWLEDGEMENTS}

Without the assistance of many people, this thesis might never have been completed. Many thanks go to Marjorie Terdal, a great advisor, whose constant encouragement, true interest, and sense of humor carried this thesis to fruition; to James Nattinger, shelley Reece, and Linda walton for their shared wigdom and guidance; to Becky Appley, whose energetic acting made the videos come alive; to Jim Baldwin, who, in the tradition of Krashen, helped provide abundant statistical input which he made comprehensible; to James Kimball of T.V. Services for glving the research a professional touch; and to my international friends for their help: Iwan, Samer, wael, Ji-young, Kwang-hee, Kumiko, Doris, Feroz, Kazuyo, Raji, Tomomi, Hideko, Beom koo, Zhuo, Carlos, Bassam, Jong-sung, Han-jin, Ali, David, Rocky, Huang-hai, Toshimasa, Shin, and seongbeom.

special thanks go to my parents for their in-depth caring during graduate studies. Doomo! Doomo!

Finally, and above all, my heartfelt thanks and gratitude go to my wife, Janet. I am indebted to her Eor her patience when I was away for aeons and for her being an all-around terrific, loving mother and wife in making our home a real oasis. Arlgatoo gozaimasu! 
TABLE OF CONTENTS

PAGE

ACKNOWLEDGEMENTS ........................ i i

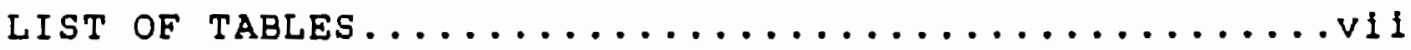

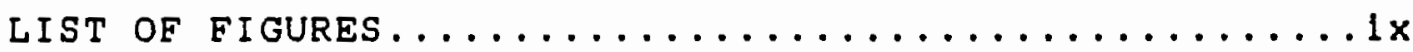

CHAPTER

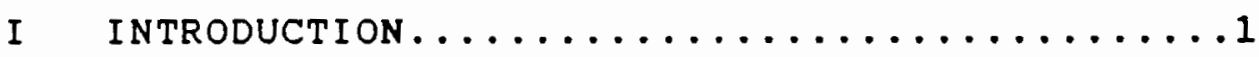

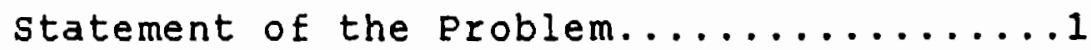

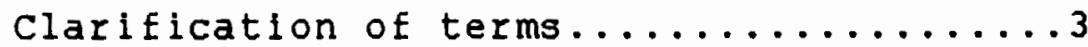

Humor/Joke

Curricular Humor

I I REVIEW OE THE LITERATURE.............6

Humor in General..................

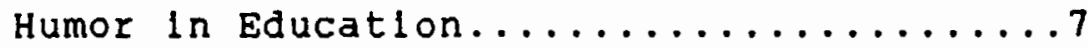

Non-curricular Humor

Currlcular Humor

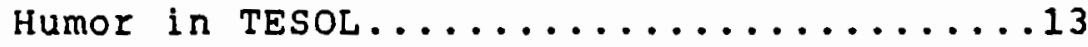

Using Humor to Enhance Cross-Cultural

Communications.................14

Dangers of Classroom Humor...........16

Some Examples of Curricular Humor......17

Suggestions for Incorporating Humor

Some Texts Which Incorporate Humor

some Texts which Exclusively Use

Humor

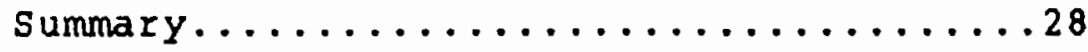




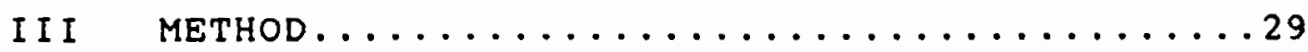

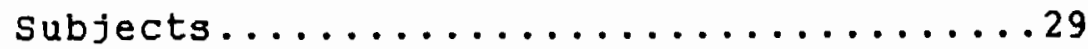

Procedures........................

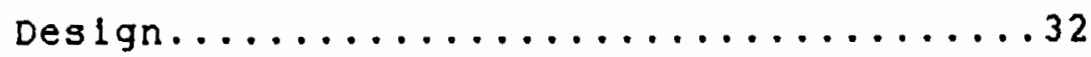

Memory and Recall

Over-all English Proflciency

Attitudes

IV RESULTS $\ldots \ldots \ldots \ldots \ldots \ldots \ldots \ldots \ldots \ldots \ldots \ldots \ldots \ldots$

Effects of a Course in Humor on Memory

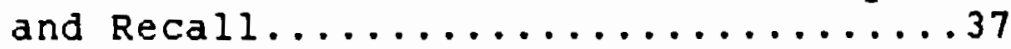

Experlmental Group

Control Group

Experimental Group and Control Group

Effects of a Course in Humor on Over-all

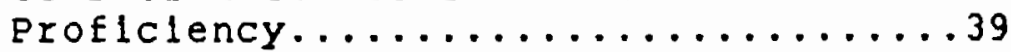

Experimental Group

Control Group

Experimental Group and control Group

Effects of a Course in Humor on

Attltudes Towards Americans........40

Differences In the subjects' Attitudes About Amerlcans and The Subjects' Attitudes About The $1 \mathrm{r}$ Ideal selves The Correlation Between The Subjects' Attitudes About Americans, Their Ideal Selves and The Memory/Recall Scores

Correlation Between The Subjects' Att ltudes About Amerlcans, The ir Ideal Selves and The MTELP Scores

v DISCUSSION AND IMPLICATIONS $\ldots \ldots \ldots \ldots \ldots \ldots 7$

summary.................... 47

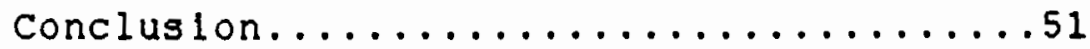


BI BLIOGRAPHY .........................

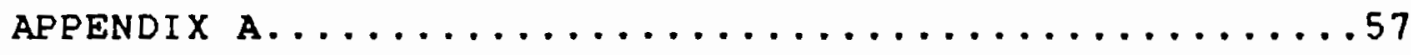

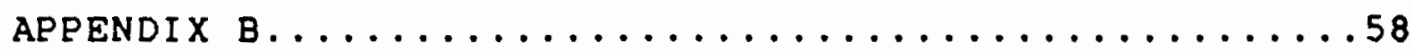

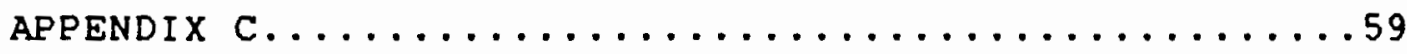

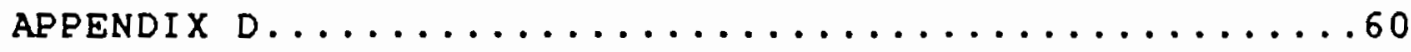

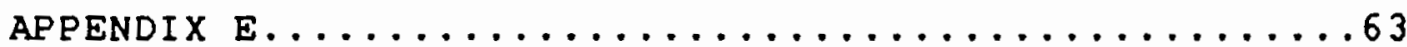

APPENDIX F.................................. 64

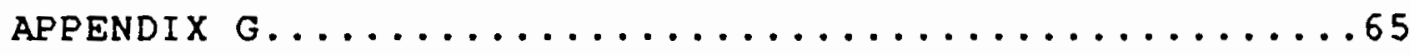


I Rating scale for Measuring Memory/

Recall of Amerlcan Jokes............. 33

I Wilcoxon Matched-Pairs Signed-Ranks Test of the Experimental Group's Pre-test

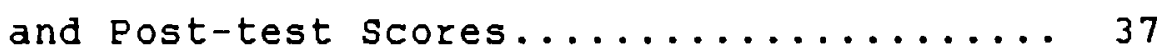

II Wilcoxon Matched-Pairs signed-Ranks Test of the Control Group's Pre-test and Post-

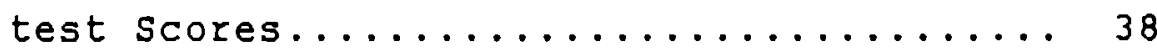

IV Mann-Whitney U-Test of the Experimental and Control Group's Pre-test and post-

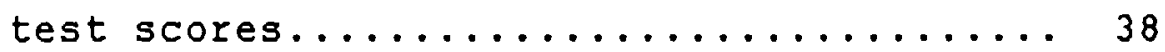

$V \quad T$-Test for Dependent Samples of the Experimental Group's MTELP scores........ 39

VI T-Test for Dependent Samples of the Control Group's MTELP scores........... 39

VII T-Test for Independent samples of the Experlmental and Control Group's MTELP scores...........................40

VII Mann-Whitney U-Test of Differences in Attitude Toward Americans Between the Experimental and Control Groups........ 41 
IX Mann-Whitney U-Test of Differences

in Attitude Toward Ideal Self Between

the Experimental and Control Groups.......

$x$ Mann-Whitney U-Test of Differences in

Attltude Within the Experimental Group

Between Attitudes Toward Americans and

Att ltudes Toward Their Ideal selves........

$X I$ Mann-Whitney U-Test of Differences in

Attitude within the Control Group

Between Attltudes Toward Amerlcans and

Attitudes Toward Their Ideal selves........

XII Spearman Rank order Correlation of the

Experimental Group's Attltudes and

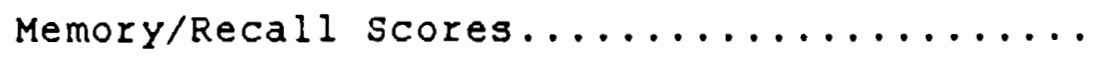

XIII Spearman Rank order Correlation of the

Control Group's Attitudes and MTELP

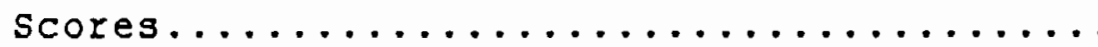

XIV Spearman Rank order Correlation of the Experimental Group's Attitudes and MTELP...

XV Spearman Rank Order Correlation of the Control Group's Attitudes and MTELP........ 


\section{LIST OF FIGURES}

FIGURE

PAGE

1. Suls' Model of the Cognitive Process

of Humor Appreciation............... 4 


\section{CHAP TER I}

\section{INTRODUCTION}

It is the opinion of many (Bailey et al, 1979; Terrel1, 1983; Altman, 1981; Trachtenberg, 1979) that humor and fun are important elements in the ESL classroom. Other than subjective experience and intuition, a recent computer search indicated that there are no published empirlcal studies on the effect of humor in the ESL classroom. The purpose of this thesis Is to discuss some uses of humor in the classroom and to investlgate empirlcally the effects of one form of humor, American fokes, in the ESL classroom.

\section{STATEMENT OF THE PROBLEM}

Tracy D. Terrell, in Methods That Work, asserts that "no instruction hour, even with adults, should be without an activity in which the target language is used for some sort of fun"(1983:281). English teachers and TESOL enthusiasts have occasionally made suggestions how humor can be pedagoglcally useful. Some texts have intentionally incorporated humor in thelr lessons. other texts have exclusively used humorous material. But is there any emplrical evidence that the use of humor enhances language learning in the classroom? The 
goal of this research was to measure and analyze the effects of a course in American jokes in a college level ESL classroom by answerlng three questions:

1) Does the use of curricular humor (Amerlcan Jokes) increase memory and recall of American fokes as measured by a dictation test?

2) Does the use of currlcular humor increase over all English proficiency as measured by the Mlchigan Test of English Language Proficlency?

3) Does the use of curricular humor have a significant effect on students' attltudes towards Amerlcans as measured by a survey? If so, does this correlate positively with memory/recall and proficlency?

The expectations by the researcher for the Experimental Group, after their taking a course in humor, were that 1) they would have slgniflcantly higher memory/recall scores than the Control group, 2) they would have achleved signiflcantly hlgher over-all proflclency scores than the control Group, and 3) the Experimental Group's higher scores on the memory/recall test and proflciency test would correlate with a more positive attitude toward Americans on the part of the Experimental Group. Th1s assumes that a positive attltude is indicative of an integrative motivation. Brown(1980), in discussing varlous studies of motivation in second language learning, describes two kinds of 
motivation:

Instrumental motivation refers to motivation to acquire a language as means for attaining instrumental goals: furthering a career, reading technical material, translation, and so forth. Integrative motivation is employed when a learner wishes to integrate himself within the culture of the second language group, to ldentify himself within the culture of the second language group, to ldentify himself with and become a part of that society (p.114).

Brown states that studies have shown that integrative motivation generally correlates with higher scores on proficiency tests in forelgn language (p.114). However, other studies (van Els, 1984) have revealed that "the relative importance of an integrative or instrumental motivation depends to a large extent on the context in which language is learned" (p.119).

\section{CLARIFICATION OF TERMS}

\section{Humor/Joke}

Humor is defined by the Webster's Third

International Rictionary (1966) as "that quality in a happening, an action, a situation, or an expression of Ideas which appeals to a sense of the ludicrous or absurdly incongruous: comic or amusing quality." A foke is defined as "something sald or done to amuse or provoke laughter: a brlef narrative designed to provoke laughter and typlcally having a climactic humorous twist or denouement." Suls (1983) describes humor as entalling a cognitive process diagrammed in figure 1. 
According to suls, this theory of humor is that

humor results when the perclever meets with an incongrulty (usually in the form of a punch ine or a cartoon) and then is motivated to resolve the incongruity either by retrieval of information in the joke or cartoon or from hls/her own storehouse of information. According to this account, humor results when the incongrulty is resolved; that is, the punch ine is seen to make sense at some level with the earlier information in the joke. Lacking a resolution the respondent does not "get" the joke, is puzzled, and sometimes even frustrated. The resolution phase is a form of problem solving, an attempt to draw information or inferences that make a link or provide a $f$ it between the initial body of the joke, cartoon, or situation and its ending (1983:42).

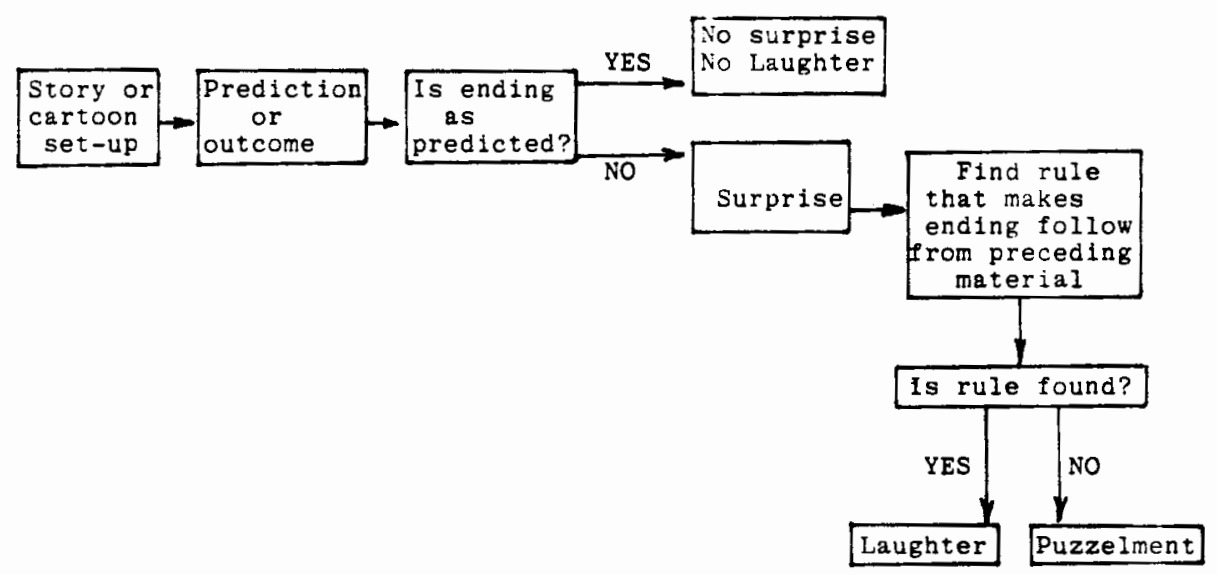

Eigure 1. Suls' model of the cognitive process of humor appreciation (1983:42).

Curcicular Humor

A distinction is made between "curricular humor" and "non-curricular humor." Curricular humor is humor that is used as the intentional object of study. studying American Jokes, Joke-telling, comedy, etc., are 
examples of curricular humor: humor itself is meant to be an essential element in the syllabus. Non-curricular humor is humor that is not the object of study, but may enter into the classroom indirectly, and at times unintentionally, through the teacher, students, text, events, etc. spontaneously inserting an amusing anecdote during a lesson is an example of non-curricular humor: it was not a planned element of the lesson. The subject of this thesis is the use of curricular humor. 
CHAPTER I I

\section{REVIEW OF THE LITERATURE}

\section{HUMOR IN GENERAL}

Humor is ublquitous. Many of the most popular television programs, books, varlety shows, movies - a vast array of media - are based on the motif of humor. Why?

Humor has many beneflts. It is a generaliy held belief that a humorous person is also a healthy person. Even the Bible says, "A cheerful heart is good medicine, but a crushed spirit dries up the bones." (Proverbs $17: 22$ ).

Humor is good not only for laughter; it can also help make us more socially consclous of human values and help us Improve life (Welss, 1981). As we laugh at ourselves, as portrayed In drama or literature, we can more easily see ourselves as we are: We can see our insecurity with others, our fears, our selfishness -a multitude of our human weaknesses and foibles. We are reminded through humor that we are humans and that even the greatest humans have flaws. This helps us to survive.

Mark Twain knew the Importance of humor in The 
Mysterious stranger, "against the assault of laughter nothing can stand." Perri, in Just a spoonful of sugar, commented on this aspect of survival. "Not pettiness, not anger, not despair - none can stand as long as we can laugh and our students can laugh with us" (1981:42). Beyond health and survival, zelgler belleves that a sense of humor is the "mark of a creatlve thinker who can stimulate others and to create feelings of good will" (1985:346). He relates creative thinking with humor. Weiss also relates the two in stating that provocative writers use humor (exaggeration, absurdities, etc.) not only to cause laughter, but also to make people think about this amazing world (1981:72).

\section{HUMOR IN EDUCATION}

Humor apparently stimulates thinking, but can it be used in curriculum to promote learning and growth? If it is helpful, who benefits the most, the teacher or the student? How best can it be used by teachers to do this? In an attempt to answer these questions, a distinction can be made between two types of humor: noncurricular humor and curricular humor.

Non-curricular Humor

Zeigler states that he believes that the proper use of humor by educational leadership has an all around positive influence. 
Leadership style is the salient factor which influences productivity and satisfaction of individuals in a school. The proper use of humor can promote flexibility, facilitate communication, provide alternative perspectives, and create a feeling of goodwill. All these factors affect school leadership and school climate" (1985:346).

From the perspective of the teacher, having a sense of humor is good medicine: Laughing at your self can help you to cope, to survive, to plow through those piles of paper. Perri (1981) thinks that it is a quality that can not be easily taught in any teacher training program, but should be an essentlal ingredient. Despite the above enthuslastic proposals for the use of humor, the suggestions seem to come from only an intultive feeling about humor, without any objective support.

sudol (1981) finds humor useful. He lists several reasons he continues to use non-curricular humor in his classroom:

1. To escape a bootcamp atmosphere

2. To break monotony

3. To relleve tedium

4. To keep interest high

5. To encourage thinking

6. To establish warmer, personal relationships

7. To encourage to do homework

8. To defuse embarrassing situations

Zelgler (1985) also lists some beneflts of non- 
curricular humor:

1. To encourage and facilitate communications

2. To enhance the quality of communication

3. To lessen hostility and create a relaxed atmosphere

4. To provide an impetus to galning inslght into a problem situation

In addition to the above, Colwell (1984) states that a sense of humor can enhance the lmage of the teacher as a healthy, balanced human belng. Students say that laughter is a safety valve for sanity in the crazy world of routines and pressures (Weiss, 1981).

Trachtenberg (1979:91) writes that humor "relaxes the tension in the classroom. It keeps students from falling asleep, and it keeps the teacher entertained, a not negligible virtue, since the high spirits of the teacher can set the tone for the whole class."

There is controversy over whether humor alds memory. Gruner, commenting on research, states that the use of humor in speeches "may or may not make a speech more memorable" (1985:144), but he offers no emplrical evidence to substantlate this. Some belleve that humor does ald memory - witness the generous use of it in the language of advertising which often uses puns to enhance memory, and thus enhance sales. 7-up clalms to be the 
"cure for the common cola", whlle Bell Telephone urges us to purchase an extension phone, "Don't run for the ring, reach for it", or a Touch Tone phone, "Punch a friend." (Lederer, 1981).

According to perrl, a sense of humor can also be helpful in error correction. She says that "students are always willing to find humor in thelr own errors. And it's easier to teach a receptive mind than a hostile one" (1981:41). With a sense of humor, spelling errors can keep a teacher young - "who can keep from smiling when finding Don Quixote spelled 'Donkey Hode'?" (Perr1 1981:42). Depending on the character of the student, the use of humor may cause amusement - or humiliation.

All of the above humor enthuslasts do thelr best to promote the use of humor. However, thelr suggestions are subjective and ill defined. Most teachers seem to agree that humor $1 \mathrm{~s}$ indeed useful, and students appear to prefer teachers who have a sense of humor, yet the notion of humor in the classroom is still largely an intultive concern.

\section{Curricular Humer}

Many skills that would ordinarliy be taught can be glven new life by a sense of humor, and students may be motivated by these kinds of humorous learning experlences (Colwell, 1984). While there 1s little empirical data that this is true, several learning 
theories point in this direction: information processing theory, "meanlngful verbal learning" theory, and arousal theory (Colwell, 1984).

1. Information processing theory states that for learning to take place, data must be efficlently stored and retrleved. Humor appears to enhance this storage and retrleval of information and thus, enhance learning. At this point however, this is fust a theory with no empirical evidence.

2. Meaningful verbal learning theory states that there needs to be meaningfulness and a structure among ideas in order for learning to occur. Humor provides a meaningful context and a structure between ideas that are unique and unusual, e.g. puns, but perhaps no more meaningful than other sorts of contexts.

3. Arousal theory says that arousal and attention are related, and that attention is related to learning; students who are aroused are alert and attentlve, they are ready and willing to learn. Curiosity is an attractive form of arousal which humor can provide by creating "conceptual incongrulty," e.g. jokes.

Far from beling a frill or add-on, humor may be instrumental in developing many types of skill and appreclation activities presently listed in many texts (some examples will be glven in the next section). Humor 
may represent a more palatable way of teaching many aspects of the current curriculum (Colwell, 1984). Colwell also adds that "Humor must be challenging, yet within the comprehensibility of the students" (1984:79). This colncides with Krashen's commprehensible input theory.

In The Natural Aporeach, Krashen (1983) ut1lizes five hypotheses to explain second language learning: 1) The acquisition - learning hypothesis, which states that aquisition is a natural, unconsclous, implicit process and that learning is a consclous, expliclt knowledge of rules. Adults can still acquire a second language. 2) The natural order hypothesis, which states that grammatical structures are acquired in a predictable order. 3) The monitor hypothesis which says that consclous learning has an extremely limited function in adult second language performance. 4) The imput hypothesis which states that we acquire language by understanding input that is a little beyond our current level of competence (comprehensible imput). 5) The affectlve fliter hypothesis whlch states that "attitudinal variables relating to success in second language acquisition generally relate directly to acquisition but not necessarily to learning" (p.26-38). That is, it may be said that teaching Amerlcan fokes and making them comprehenslble, according to krashen's 
hypotheses, may be an alternative approach to language acquisition.

\section{HUMOR IN TESOL}

ESL/EFL teachers are just as likely to experience all the pressures and pain that non ESL teachers experlence. Along with the usual difficulties of any teaching responsibility, teaching a language to nonnatives is a formidable task. Needless to say, a sense of humor can be a great help to the teacher in this demanding situation. Humor can blot out pain, fust as McMurphy, in one Elew over the cuckoo's Nest, taught his "twelve disciples" how to laugh and blot out the pain in their lives. Approprlate humor may be a therapeutic tool the wise teacher can use.

Besides belng a vital help to the teacher in a non curricular way, humor can enhance the curriculum itself (More speciflc examples will be discussed under "Some Examples of Curricular Humor"). For example, humorous 11terature, as well as other kinds of Ilterature, can be used in a writing class to open up many kinds of communication processes. The teacher can ask "what comes to your mind?" (Welss, 1981:72), or "Have you ever experienced this before?" questions about the humor which may become a basis for discussion, writing asslgnments, fournals, etc. 
The ESL teacher can also use humor in error correction, for example, by asking, "Is there anything strange about the meaning of the sentence you wrote here?" about a sentence like "people who use bleth control methods that smoke a lot are in danger of having retarded children." If the student does not see the mistake, the teacher (exercising the funny bone) can write the sentence, "Those smoking birth control methods are interesting!" or, "I've never heard of a smoking bleth control method before." Hopefully this will encourage the student to self-correct the mistake and laugh at the same time.

Humor provides a treasure of Ideas that can be used in listening, speaking, reading and writing classes by using jokes, puns, videos of sit-coms, movies, or television blooper shows; recordings of comedians, comic strips, books by comedlans, e.g. Erma Bombeck, and much more. Humor is everywhere - even in shakespeare! - It just takes a sense of humor, creatlvity, and wisdom on the part of the teacher to use it well.

USING HUMOR TO ENHANCE CROSS-CULTURAL COMMUNICATIONS

The effective acquisition of language, according to current theories, e.g. Krashen's Natural Approach, requires, among other things, a relevant, meaningful 
context. Krashen states that "language is best taught when it is used to transmit messages, not when it is explicitly taught for consclous learning." Meaning, which is more important than form, can be alded by context. Language is formed within a cultural context which can provide helpful clues to meaning.

In a recent master's thesis, Travano (1986) showed that the ability to create and appreciate humor was an Indicator of intercultural communication effectiveness One goal of ESL is that students become effective intercultural communicators. It would appear then, that an appreclation of American humor would be a worthwhile goal in an ESL curriculum.

The goal of teaching American humor would be not just the ability to comprehend and produce jokes, but also "communlcative competence", the ability to know who you are, what to say, who to say it to, how to say 1t, why you say 1t, when to say 1t, and where to say it (Irving, 1985 ).

To help a student become a competent communicator, the culture of the target language needs to be studied. All cultures can be categorized into five areas (Irving, $1985: 139)$ :

1. Human nature

2. Man-nature relationship

3. Time sense

4. Activity

5. Social relations 
In each of the above areas, approprlate American humor can be found and used in a curriculum to help the student further understand American culture and thus grow toward communicative competence.

Irving states the conviction that ESL teacher training programs "need to redefine and redesign their goals, content and methodologies to teach communication in a cultural context" (p.141). Using curricular humor might help to achieve this goal.

\section{DANGERS OF CLASSROOM HUMOR}

Perri (1981), while enthusiastic about the use of humor, cautions about the unwise use of non-curricular humor; laughter at the wrong time can wreck a mood which a teacher has worked hard to bulld. Humor needs to be proper, appropriate and wisely used.

sudol (1981) discusses a list of dangers in the misuse of four kinds of non-currlcular humor: fokes, clowning around, teasing, and sarcasm, which he says are harmful if not used wisely.

1. Joking - can lead to a playroom atmosphere or can signal "end of learning" time.

2. Clowning around - can lead students to think that the teacher is a clown or incompetent.

3. Teasing - may be insulting or offensive, may cause loss of respect, or can breed contempt. 
4. Sarcasm - can be read as malicious and can do irreparable damage.

In the ESL/EFL classroom, according to this researcher's experience, the teacher needs to exercise extreme care in the use of non curricular humor, especlally teasing and sarcasm. If unsure about approprlateness, "steer clear" is good advice.

Curricular humor 1 s easler to handle because 1 is not supposed to be taken personally, although caution must be taken: culturally insensitive, sexist material, etc., should be avolded.

SOME EXAMPLES OF CURRICULAR HUMOR

Colwell (1984) lists uses of humor in language art classes:

A. Receptive

1. Reading - understanding and appreclating:

a. jokes, puns, riddles

b. exaggeration

c. figures of speech

d. understatement/overstatement

e. stylistic elements

f. sarcasm

2. Listening - appreciation of humor and delivery styles $\mathrm{In}$ : 

a. puns, Jokes, riddles
b. monologues
c. dialogues
d. skits

B. Generative

1. Writing - creation of
a. captions, slogans
b. puns
c. punch lines
d. skits
e. comics
f. monologues
g. dialogues
h. satire
i. essays

2. Speaking - delivering original humor in
a. monologues
b. dlalogues
c. skits

This is a comprehensive list showing that, far from being a frill, humor can be a substantial component in all of the major areas of TESOL. Without being exhaustive, the following is a sample of some work being done in the area of curricular humor.

Suggestions for Lncerperating Humer

A popular medlum for utliling humor in education 
is the comic strip. "Many American comlc strips lean toward sophisticated satire of American life or humanity In general and are a rich resource of materlal for language and culture study" (Elkins, 1971). Elkins offers helps in the use of comlc strips by discussing the baslc types and uses, the different cultural messages given, different topics covered, and lists a ten point system for critical analysis of any comic strip. He also includes some useful guidelines for selection of comic strips for the ESL teacher.

Demetrulias (1982) has used cartoons to teach American high school students vocabulary, reading, speaking, and testing. She selects cartoons and blots out certain words or phrases. The students are to fill in the blank space with words that 1) are clear, 2) make sense, and 3 ) help create a funny situation. Reading each other's cartoons can lead into some lively discussions.

van Dyk (1981) teaches a comedy course by having students write humorous essays, plays, skits, etc., that are based on reading materlal they cover. Van Dyk teaches American High School students, but the method could be adapted for an ESL syllabus.

Monnot and Klte (Monnot et al, 1974) argue that the pun, with its intentional ambiguity, can be used profltably at all levels of the language acquisition 
process. They descrlbe the process at work in puns and illustrate how puns can be beneficially applied in the classroom.

Monnot states that the intentional ambiguity of a pun, rather than being a llablitty, can be used as a problem solving technique in varlous stages of language learning. Puns combine humor with a lingulstic task which helps to whet the appetite of the student.

Several reasons are glven for puns belng pedagogically useful:

1) They are Immediate - a pun is created for instant recognition.

2) They bring together disparate semantic fields in a surprising way.

3) Advertising puns can be used to teach current English speech as well as to introduce cultural attitudes of Americans. Puns hinge on various language aspects which Monnot clearly describes. Puns can be created by lexical, syntactic and phonologlcal ambigulty. These different types of amblgulties can be utlilzed to teach a specific polnt. Puns are also created by homographic and homophonic ldloms or words, e.g. "Go to the dogs!" as an advertisement for callente race tracks. Phonemic changes are also used to create puns: "There are two sides to every tissue," an advertisement for Aurora 
toilet paper.

In suggesting pedagogical uses of puns, Monnot states that puns are useful "from elementary pronunciation drill to the more sophisticated dialectprobing seminar"(1974:68) and proposes units on vocabulary, syntax, phonology, orthography, dlalect, and culture.

In regards to culture, Monnot asserts that the pun offers a rlch resource of information:

From "It's the way English keep their gin up" (Gordon's gin) to "when you'd like to go bra-less but nature let you down"(Olga bras) a quasi infinite range of topics can be uncovered. Units on drinking habits, sexual habits, women's liberation, pollution, ethnic groups, eating habits, automobiles, sports, illnesses, yes, even intellectual I ife ("Having a cerebration, quote Newsweek" or "It goes to your head" (The New york Times), all stemming from puns, are readily available to the alert teacher(p.70-71).

Trachtenberg(1979) advocates using another form of humor, foke telling, in ESL classes. She describes foke telling as a speech act which requires a great deal of communicative competence on the part of the speaker and listener. She also explains why humor is important:

The projection of a sense of humor is in fact a key element that must be ecouraged if the student of English as a second language is indeed to be himself in an English speaking milleu. As teachers, we can and do encourage this humor in a number of ways - with games, with funny questions, and, perhaps most importantly, with an atmosphere in the class that puts the students at their ease (p.90).

Joke telling, according to Trachtenberg, has a 
number of merits: 1) They are short and can be a mini-lesson in vocabulary, grammar, etc. 2) They are rule governed. 3) They provide various speech patterns - they come in the form of question and answer, narrative, insult, dialogue, apology, etc. 4) They are common to all cultures. 5) They can be utilized to teach about cultural values. 6) They can be generallzed into other speech acts, e.g. narratives and conversation. 7) Jokes are funny, and thus help to ease tension and keep interest high(p.90-91).

Trachtenberg goes on to share various ways that joke telling can be pedagogically useful in the classroom. She discusses the use of rlddles, the narrative Joke, and eliciting Jokes. For example, she states that the ridale is often thought of as childish and unworthy of consideration. But, as Trachtenberg asserts, riddles can be useful to an ESL teacher. The following joke can be used to teach "what" questions, interrogative forms, and lexical ambiguity:

"What has wheels and flles? A garbage truck." The amblguity of the word "flies" is presented in the form of a joke. In the question 1t appears as a verb, but in the solution is used as a noun. This syntactic shift is what makes the joke funny, and is the element which the student needs to understand in order to "get" the foke(p.92). 
Trachtenberg makes a strong case for the use of jokes in her article. She states that joke-teling can be used effectively to teach grammar, vocabulary, and appropriate speech behavior:

The very act of telling fokes creates a genuine speech event, in which students and teacher are natural participants. Few of us, I believe, would knowingly want to waste this opportunity (1979:98).

Seme Texts whlch Incorperate Humer

some texts intentionally utilize humor in a less direct fashion, such as the American streamline series (Hartley et al, 1984). The serles can be used to teach listening, speaking, reading, and writing, but is primarily a speech text. The text is full of varlous styles of drawings, paintings, photographs, water colors and cartoon-like deplctions of conversational sltuations, many of which are humorous. For example, in a lesson titled "Never on sunday," there is a drawing of a minister talking to an embarrassed looking man in front of a church. The target structure of the lesson is frequency adverbs with the simple present. Here is the model dlalogue:

Reverend: Oh, hello there, Mr. Benson. I never see you in church nowadays.

Benson: Oh, well, uh, Reverend wlison, that's true. But my wife always goes to church.

she goes every sunday.

Reverend: I know. But you never come. 
Benson: Well, I rarely come...but I'm always there on Christmas and Easter.

Reverend: But what about Sundays, Mr. Benson?

Benson: Uh, I'm usually busy on sundays. For example, I often wash my car on sunday mornings.

Reverend: I see. Why don't you wash your car on saturday next week?

Benson: Oh, I can't do that, Reverend.

Reverend: why not?

Benson: It's my son's wedding day next saturday. I'm going to church!(Hartley 1984:35).

Interspersed among more serlous lessons, humorous encounters like the above provide an enjoyable change of pace and present the target language in an interesting context.

Another text that intentionally uses humor as a tool is Between The Lines(zukoowski/Faust et al, 1983), a reading text for intermediate level students. In one lesson titled "Art and Humor," the reading text is a discussion and description of cartoons. The reading selection is followed by a series of four cartoons which are utilized for various learning activities such as discussions and writing captions. The following is written above one of the cartoons:

A cartoon consists of an illustration - a drawing - and often a caption as well. A caption is the written part of the cartoon. The illustration is not completely realistic; certain characterisics are exaggerated, made bigger than they really are. Which characteristics are exaggerated in the following cartoon?(p.73). 
Through the use of cartoons, zukowsk1/Faust has created an interesting, humorous experience in learning to read English. Cartoons are only one of many useful means of creating interest, but they are unique in that they contain humor which helps provide needed varlety.

Some Texts which Exclusively Use Humor

H111 (1977) has written a serles for reading called Elementary storles for Reproduction in which he uses short storles accompanled by learning exercises. Above each story is a cartoon-like drawing which illustrates the situation in the story. Here's an example of one story:

Dick was seven years old, and his sister, Catherine, was five. One day their mother took them to their aunt's house to play whlle she went to the big city to buy some new clothes.

The children played for an hour, and then at half past four thelr aunt took Dick into the kitchen. She gave him a nice cake and a knife, and said to him, "Now here's a knlfe, Dick. Cut this cake in half and glve one of the pleces to your sister, but remember to do it like a gentleman."

"Like a gentleman?" Dick asked. "How do gentlemen do it?"

"They always give the bigger plece to the other person," answered his aunt at once.

"Oh," said Dick. He thought about this for a few seconds. Then he took the cake to his sister and said to her, "Cut this cake in half, Catherine" (p.48).

A teacher can help improve reading comprehension by helping the student understand the humorous and clever 
way the boy followed his aunt's coaching.

What's So Eunny: A Eorelgn student's Introduction to American Humer by Elizabeth Clalre (1984) deals directly with the topic of American Jokes. It is written for the intermediate and advanced college conversation classes and covers a wide range of subjects: chlldren's humor, college life, lawyers, waiters, barbers, people in power, reglonal and ethnic jokes, etc. It includes a chapter on the structure of a foke and also a chapter on "how to tell a foke." Clalre includes some helpful suggestions for text use:

1. The teacher can begin the class by sharing a joke that is relevant to the chapter or by introducing one of the discussion questions at the end of each chapter.

2. Vocabulary that might be difficult can be discussed. The students can attempt to use the words in a sentence.

3. The chapter can be a reading assignment.

4. The following day vocabulary can be revlewed and the ldioms at the end of the chapter can be introduced.

5. The teacher can ask ask if there were any difficulties with the readings. Which jokes did they like the most? Which jokes were not funny to them? This can be done in one large 
group or in small groups, palrs, etc. Each group can report the least liked/most liked jokes, controversies, funny stories, etc.

6. Students can share jokes they have heard and/or can be encouraged to share jokes from their own country which relate to the toplc under discussion.

Clalre also gives some useful suggestions for additional activities:

1. The teacher can assign students to watch a currently popular T.V. situation comedy and report to the class on the success or difficulty of understanding humor. (Perhaps an evaluation form could be used).

2. The teacher could tape programs to playback In class to bring current trends and topics of humor into the classroom. Discussion can be about types of humor used, butts of jokes, and word plays ut1l1zed.

3. The teacher can have students read a column written by current Amerlcan humorlsts such as Erma Bombeck, Art Buchwald or Russell Baker.

4. Students can be encouraged to bring in fokes they have heard or to clip cartoons for a class humor collection or bulletin board. 
SUMMARY

Humor has a universal appeal and can be effectively utilized in TESOL. Humor not only has affective beneflts, if used wisely, but also can be a significant pedagogical tool. Although further research is needed, most users belleve that the use of humor enhances learning. This has positive implications for TESOL. Humor has often been neglected or considered "add-on", but more recently many non-TESOL and TESOL instructors are discovering humor's value and are incorporating it into new texts and syllabuses. However, all of the above endorsements of humor are intuitive rather than empirical; the categories covered seem to be emotional and subjective rather than objective and verlflable. Are there any veriflable effects of humor on memory, proficiency, and attitudes? Further research is needed. The next chapter will deal with the method used in this research to obtain such empirical data. 


\section{CHAP TER III}

METHOD

SUBJECTS

To measure the effects of humor, a ten lesson, flve week course in Amerlcan Jokes was taught to ten level III students enrolled in the Center for English as a second Language program at Portland state University. Level III students are considered to be students who are in the upper-intermediate level of English proficiency, as determined by TOEFL scores of $460-490$. The subjects were selected during ESL registration for winter term, 1987, and were all current ESL students. The humor class comprised a total of 2 hours of weekly ESL instruction. A Control Group was made up of ten level III ESL students. The subjects were from varlous countries:

\begin{tabular}{llll} 
Experimental Group & & \multicolumn{2}{l}{ Control group } \\
Japan & 3 & China & 4 \\
Korea & 3 & Indonesia & 2 \\
Indonesia & 1 & Korea & 1 \\
Syria & 1 & Equador & 1 \\
Germany & 1 & Saudi Arabia & 1 \\
Pakistan & 1 & Iran & 1
\end{tabular}


None of the subjects had been in the United states more than three months and a majorlty had been here less than one month. They had all studied English in their native countries for at least three years and a majorlty had studied approximately $s 1 x$ years.

\section{PROCEDURES}

Ten classes were held over a flve-week perlod. The classes started during the third week of a ten week term and concluded during the seventh week. All of the classes were held in a university classroom from 2 PM until 2:50 PM on Tuesdays and Thurgdays. The humor class followed a normal day of intenslve English classes which lasted four hours. A pre-test, to measure memory and recall, was given to both the Experimental Group and the control Group at the beginning of the course and a post-test was given two weeks after the end of the course. An attitude survey, to measure attitudes toward Amerlcans, was taken the day before the last lesson.

The syllabus for the ten classes conslsted of fokes about ten different topics:

Lesson \#1 Dieting

2 Psychiatrists

3 Good News/ Bad News

4 stupidity

5 College Life 


\author{
6 Work \\ 7 Waiters and Diners \\ 8 Government \\ 9 Marriage \\ 10 Children's Humor/ Riddles
}

A typical lesson plan consisted of the following elements :

1. A video presentation of a foke. The foke was played 3-4 times.

a. The flrst time, the foke was played all

the way through. The subjects were asked if they recognized the tople of the joke.

b. On the second showing, the video was stopped fust before the punch line and the subfects were asked "what do you expect to hear?"

c. The third-fourth time the joke was shown with the subjects reading along with a transcript.

2. The vocabulary, syntax, and situation were discussed.

3. A handout of approximately a dozen related Jokes was read and discussed.

4. Subjects were invited to share similar jokes from their own countries. 
5. Since one of the goals of the course was to encourage the subjects to understand and experlence Amerlcan humor on a regular basis over the flve week perlod, a non-obligatory assignment was suggested:

a. Try the joke on a friend or American and record the results (Appendix A).

b. Be on the lookout for other jokes and bring then to class.

DES I GN

Memory and recall.

To test memory and recall, a pre test and a posttest were administered. Each test consisted of a video presentation of ten different jokes. The topics of the ten fokes correlated with the topics in the ten lessons. Test procedure:

1. For both the pre-test and the post-test, all of the subjects were tested together in one sitting whlch lasted one hour.

2. An answer form (appendix $B$ ) was handed out and explained.

3. After each joke was presented, the subjects were given five minutes to fill in the answer form by

a. answering a question about the topic of 
the joke (this device was used as a distractor) and

b. writing the joke from memory.

Test measurement:

1. Each foke in the pre-test and post-test was analyzed by two EsL teachers. They were asked to clrcle the Items whlch they believed were essential to understanding the foke. In order to measure the test results as accurately as possible, the two analyses were compared and used to decide which items were essential for the foke to be complete (having both incongrulty and resolution).

2. A rating scale was devised in order to score each joke according to how many of the essential items were included (Table I).

\section{TABLE I}

RATING SCALE FOR MEASURING MEMORY/RECALL OF AMERICAN JOKES

scere Measurement

$0 \ldots$.... Nothing written

$1 \ldots \ldots 208$ of the joke written.

Consists of words, phrases, and up to, but not necessarlly, one sentence.

$2 \ldots \ldots 30 \%-808$ of the joke written. Consists of 2-3 sentences.

$3 \ldots . .90 \%$ of the foke written. It is 
complete except that the element which causes incongrulty, e.g. the punch line, is missing.

4.....1008 complete. The joke contains all elements which are necessary for incongruity and resolution.

$5 \ldots . .$. has added information which if missing will not make the joke incomplete, but when added to \#4 above enhances the style.

3. The retelling/recall of each foke as 1 t was written by the subjects in the tests was rated according to the rating scale. To insure inter-rater reliability, a second ESL teacher independently rated all of the jokes and the results were compared with the researcher's ratings. If the difference in ratings was 0 to 1 point, the rating was consldered rellable. A difference of 2 or more points was considered unrellable. The inter-rater reliability was .8 .

The scores of all the ten jokes were added up for a total score for each subject. Each subject had two scores, a pre-test score and a post-test score, which were statistically analyzed for slgnificant differences.

Over-all English proficiency.

To test over-all English proficlency, the subjects' scores on the Michlgan Test of English 
is a 100 item test of English grammatical usage, vocabulary and reading comprehension. The test is given at the beginning and end of each quarter to all CESL students on a recommended basis. Not all of the subjects had taken the test both before and after the course in humor; consequently only nine Experimental Group and $s 1 x$ Control Group scores were avallable for analysis. The test scores were statistically analyzed for signiflcant differences.

\section{Attitudes.}

To measure the subjects' attitudes, and their relationship to test scores, a semantic differential (SD) was used. A simplified version of Pullen's (1978) semantic differential, an instrument constructed from scales validated in cross-cultural research with Japanese subjects, was utllized. The instrument was used to measure two attltude variables: "The way Amerlcans are" and "The way I would like to be."

The semantic differential was developed by C.E. Osgood (Osgood et al, 1957) and consists of pairs of adjectlves, such as good-bad, fast-slow, etc., separated by a seven point scale (appendix $C$ ). The subjects were asked to pick one of the seven points to indicate how well an adfective applies to a concept belng rated. For example, a subject was to rate the concept "The way I would like to be": 
THE WAY I WOULD LIKE TO BE
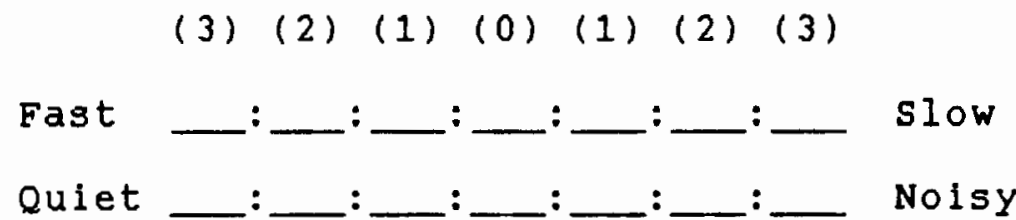

If the subjects thought that they wanted to be very "fast," the slot closest to "fast" would be marked with an $x$ (under "(3)"). If the subject wanted to be slightly quiet, the slot under (1) would be marked (see appendix $C$ for a sample of the instruction sheet).

The responses of the survey were statistically analyzed to determine any differences and correlations between the subjects' attitudes towards Americans, attitudes toward an ideal self, the memory/recall scores, and the MTELP scores.

In order to make the measurement as Indirect as possible, rather than basing it on self report, the instrument was presented under the guise of a "Survey of Metaphorical Usage of ESL Learners." Along with the target concepts of "The way Americans are," and "The way I would like to be," flve other concepts (dream, moon, television, pleasure, and city) were included to malntain the gulse of a survey of metaphorlcal usage.

The semantic differential survey was taken at one sitting. Nine members of the Experimental Group and nlne members of the Control Group were present. 


\section{RESULTS}

After the researcher administered a pre-test, taught a course in American humor, administered an attitude survey, gave a post test, and then statistically analyzed the results, some provocative differences and correlations appeared.

EFFECTS OF A COURSE IN HUMOR ON MEMORY AND RECALL

\section{Experimental Group}

To measure differences in scores between the pretest and the post-test, the wilcoxon Matched-Pairs signed-Ranks Test was used in order to make a single comparison using data that is non-parametric. Differences in scores between the pre-test and the posttest, according to the wilcoxon Matched-pairs signedRanks Test, were not significant (Table I I .

TABLE I I

$$
\begin{aligned}
& \text { WILCOXON MATCHED-PAIRS SIGNED-RANKS TEST OF THE } \\
& \text { EXPERIMENTAL GROUP'S PRE-TEST AND } \\
& \text { POST-TEST SCORES } \\
& \text { Sum of Positive Ranks } \quad \mathrm{T}=44.5 \\
& \text { Sum of Negative Ranks } \begin{array}{r}
\mathrm{T}=21.5 \\
\mathrm{~N}=11
\end{array} \\
& \text { Evaluated } \mathrm{T}=21.5 \text { as not significant }
\end{aligned}
$$


centrel group

Differences in scores between the pre-test and the post-test, as revealed by the wilcoxon Matched-Palrs signed-Ranks Test, as in the Experimental Group, were not signiflgant(Table III).

\section{TABLE I I I}

WILCOXON MATCHED-PAIRS SIGNED-RANKS TEST OF THE CONTROL GROUP'S PRE-TEST AND POST-TEST SCORES

$$
\begin{array}{ll}
\text { Sum of Positive Ranks } & T=11.5 \\
\text { Sum of Negative Ranks } & T=43.5 \\
& N=10
\end{array}
$$

Evaluated $T=11.5$ as not significant

Experimental Group and control Group

To measure differences in scores between the Experimental Group and the Control Group, the MannWhitney U-Test was used. This test is used to make multiple comparisons using data that is non-parametric. In comparing the differences in scores between the Experimental Group and the Control Group, as shown by the Mann-Whitney U-Test (Table IV), a significant difference $(P<.05)$ was found.

\section{TABLE IV}

MANN-WHITNEY U-TEST OF THE EXPERIMENTAL AND CONTROL GROUP'S PRE-TEST AND POST-TEST SCORES

$\begin{array}{lll}\text { For First Sample, } & N=11 & U=81 \\ \text { For Second Sample } & N=10 & U=29 \\ \text { Level of } U=29 & & \end{array}$

Contrary to expectation, the differences in 
scores revealed that the control Group attained significantly higher scores than the Experimental group.

EFFECTS OF A COURSE IN HUMOR ON OVER-ALL PROFICIENCY

\section{Experimental Group}

The Experimental Group's MTELP scores were analyzed by utilizing a T-Test for Dependent samples. The T-Test for dependent samples is used for parametric statistics. Dependent samples exist when the pre-test and post-test scores belong to the same person. The TTest revealed that the scores had significantly Increased from test \#1 to test \#2 (Table V).

\section{TABLE V}

T-TEST FOR DEPENDENT SAMPLES OF THE EXPERIMENTAL GROUP'S MTELP SCORES

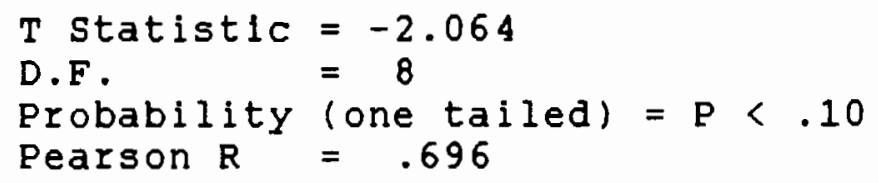

\section{control Group}

According to a $\mathrm{T}$-Test for Dependent samples (Table VI), no significant difference was found between the control Group's two MTELP scores.

\section{TABLE VI}

T-TEST FOR DEPENDENT SAMPLES OF THE CONTROL GROUP'S MTELP SCORES

T statist1c $=-0.749$

D.F. $=5$ 


$$
\begin{aligned}
& \text { Probablilty (one talled) = not significant } \\
& \text { Pearson } R=0.679
\end{aligned}
$$

\section{Experimental Group and control group}

Analyzing the differences between the two groups, a T-Test for Independent samples was used. Independent samples exlst when scores belong to different persons. The $T$-Test revealed that there was no significant difference (Table VII).

\section{TABLE VII}

T-TEST FOR INDEPENDENT SAMPLES OF THE EXPERIMENTAL AND CONTROL GROUP'S MTELP SCORES

$$
\text { Sample } 1 \text { Sample } 2 \text { T } D F
$$

$\begin{array}{lcccc}\text { N } & 9 & 6 & & \\ \text { Mean } & 7.444 & 2.167 & 1.095 & 13 \\ \text { S.D. } & 10.224 & 7.083 & & \\ & \text { Probability } & = & \text { not } & \text { significant }\end{array}$

EFFECTS OF A COURSE IN HUMOR ON ATTITUDES TOWARD AMER I CANS

The day before the last lesson in American humor, a survey was taken to measure the subjects' attitudes toward Americans and toward themselves. The results of the survey were analyzed in three ways:

1. Differences in attitudes toward Americans and toward their ideal self

2. The correlation between the subjects' attitudes toward Americans, thelr ideal 
selves and the memory/recall test scores.

3. The correlation between the subjects' attitudes toward Americans, their ideal selves and their MTELP scores.

Differences In The subjects Attitudes About Americans and The subjects' Attitudes about The is Ideal selves

Four measurements were made:

1. Is there any significant difference between the Experlmental Group's attltude toward Americans and the Control Group's attitude (The way Amerlcans are)?

According to the Mann-Whitney U-Test (Table VIII), there where five questions which showed significant differences: questions four, flve, elght, nine and ten. These differences can also be seen graphlcally in appendix D. After teaching a course in American humor, the Experimental group did not see Americans as "easy," "good," "cheerful," "comfortable," or as "pleasant" as the control Group did

\section{TABLE VIII}

MANN-WHITNEY U-TEST OF DIFFERENCES IN ATTITUDE TOWARD AMERICANS BETWEEN THE EXPERIMENTAL AND CONTROL GROUPS

Question

1

2
U-value

33

33

38.5
Signiflcance

ns

ns

ns 
4

5

6

7

8

9

10
24

21.5

30

31.5

25

21.5

21
$P<.10$

$P<.05$

ng

ns

$R<.10$

$P<.05$

P $<.10$

2. Is there any significant difference between the Experimental Group's attitude toward their ideal self and the Control Group's attitude about their ideal self (The way I would like to bel?

The Mann-Whitney U-Test (Table IX) revealed four significant differences: questions two, five, nine, and ten. After the humor course, the Experimental Group responded that they would not like to be as "happy," "good," "comfortable," or "pleasant" as the control Group would.

TABLE IX

MANN-WHITNEY U-TEST OF DIFFERENCES IN ATTITUDE TOWARD IDEAL SELF BETWEEN THE EXPERIMENTAL AND CONTROL GROUPS

Question

1

2
U-Value

35

23.5

40
Significance

ns

P $<.10$

ns 
4

5

6

7

8

9

10
0

9

36.5

37

40

11.5

16 ns

$\mathrm{P}<.005$

ns

ns

ns

$\mathrm{P}<.005$

$\mathrm{P}<.025$

3. Is there any significant difference within the Experimental Group between their Att 1 tudes towards Americans and their attitudes toward thelr ideal selves (between "The way Americans are" and "The way I would Iike to be")?

The Mann-Whitney U-Test (Table $X$ ) revealed significant differences in four questions: four, flve, six, and nine. The Experimental Group sees Americans as not as "easy," "good," "quiet," or as "comfortable" as they would like to be.

\section{TABLE X}

MANN-WHITNEY U-TEST OF DIFEERENCES IN ATTITUDE WITHIN THE EXPERIMENTAL GROUP BETWEEN ATTITUDES TOWARD AMERICANS AND ATTITUDES TOWARD THEIR IDEAL SELVES

Question

1

2

3

$$
\text { U-Value }
$$

35.5

30

34.5 signiflcance

ns

ns

ns 


$\begin{array}{llc}4 & 23.5 & \mathrm{P}<.10 \\ 5 & 12.5 & \mathrm{P}<.01 \\ 6 & 15 & \mathrm{P}<.01 \\ 7 & 28.5 & \mathrm{ng} \\ 8 & 38 & \mathrm{ng} \\ 9 & 25 & \mathrm{P}<.10 \\ 10 & 32 & \mathrm{~ns}\end{array}$

4. Is there any slgniflcant difference within the Control Group between their attitudes toward Americans and their attitudes toward their ldeal selves (between "The way Americans are" and "The way I would like to be" )?

The Mann-Whitney U-Test (Table XI) showed that there were significant differences in six questions: two, five, six, eight, nine, and ten. The control Group does not see Americans as "happy," "good," "quiet," "lonely," "comfortable," or as "pleasant" as they would like to be.

\section{TABLE XI}

MANN-WHITNEY U-TEST OF DIFFERENCES IN ATTITUDE WITHIN THE CONTROL GROUP BETWEEN ATTITUDES TOWARD AMERICANS AND ATTITUDES TOWARD THEIR IDEAL SELVES

Question
U-Value

30.05
Signiflcance

ns 


$\begin{array}{llc}2 & 15 & \mathrm{P}<.01 \\ 3 & 33 & \mathrm{~ns} \\ 4 & 36 & \mathrm{~ns} \\ 5 & 4.5 & \mathrm{P}<.001 \\ 6 & 8 & \mathrm{P}<.001 \\ 7 & 30 & \mathrm{~ns} \\ 8 & 26 & \mathrm{P}<.10 \\ 9 & 12 & \mathrm{P}<.005 \\ 10 & 13 & \mathrm{P}<.01\end{array}$

The Correlation Between The subjects' Attitudes About Americans, Their Ideal selves and The Memory/Recall scores

To measure a possible correlation between attitudes and scores, the spearman Rank order correlation was used. This device is used to measure correlations using data that is non-parametric. According to the spearman Rank order Correlation, no significant correlation was found in elther the Experimental Group or the Control Group (Table XII and Taable XII).

TABLE XII

SPEARMAN RANK ORDER CORRELATION OF THE EXPERIMENTAL GROUP'S ATTITUDES AND MEMORY/RECALL SCORES

$$
\begin{aligned}
& N=9 \\
& r h o=.128 \\
& \text { signiflcance }=n g
\end{aligned}
$$


SPEARMAN RANK ORDER CORRELATION OF THE CONTROL GROUP'S ATTI TUDES AND MTELP SCORES

$$
\begin{gathered}
\mathrm{N}=7 \\
\text { rho }=.571 \\
\text { significance }=\mathrm{ns}
\end{gathered}
$$

Correlation Between the Subjects' attitudes About Americans, Their Ideal selves and the MTELP Scores The only significant difference found was in the Experimental Group where the greater the difference in attitudes toward Americans and their ldeal self, the greater was the improvement on the MTELP (Table XIV).

\section{TABLE XIV}

SPEARMAN RANK ORDER CORRELATION OF THE EXPERIMENTAL GROUP'S ATTITUDES AND MTELP

$$
\begin{aligned}
N & =8 \\
\text { rho } & =.675 \\
\text { Significance } & =P<.10
\end{aligned}
$$

As a consequence of $\mathrm{N}$ being too low, no slgniflcant difference was found in the Control Group (Table XV).

TABLE XV

SPEARMAN RANK ORDER CORRELATION OF THE CONTROL GROUP'S ATTITUDES AND MTELP

$$
\begin{gathered}
\mathrm{N}=4 \\
\text { rho }=-.6 \\
\text { Signiflcance }=\mathrm{ns}
\end{gathered}
$$




\section{CHAPTER $V$ \\ DISCUSSION AND IMPLICATIONS}

\section{SUMMARY}

The first of the three research questions was "Does the use of curricular humor increase memory/recall of Amerlcan Jokes?" As revealed by statistical analysis, no slgniflcant difference was found within the Experimental Group or the control Group, but a slgniflcant difference, $P<.05$, was found between the two groups. However, contrary to expectation, it was not the Experimental Group whose memory improved, but the Control Group's.

What this means is that the course in curricular humor had no apparent signiflcant effect on the Experimental Group's ability to remember or recall American Jokes. Also, desplte the fact that the Experimental group had taken a humor course, it was the Control Group's scores that had apparently improved.

There are two possible explanations for the above results. Flrst, the explanation may be in the task 1tself. Perhaps the jokes were so short that the memory/recall task was not challenging to elther group. However, the scores for both groups (appendix E) show 
that out of a possible perfect score of 50, the highest mean score was 26 , possibly indicating that the task may have been a sufficient challenge. second, the explanation may be in the technique. Although the Experimental Group was taught the structure of American jokes, thus theoretically provlding a schema, this did not seem to improve the ablilty to recall jokes in comparison with the control Group.

The second of the three research questions was "Does the use of curricular humor increase over-all English proficlency?" statistical analysis showed that there was no significant difference within the control Group or between the Experimental Group and the Control Group, but that there was a signiflcant difference, $P<$ .10, within the Experimental Group: the Experimental Group's scores improved from test \#1, which was given before the humor course, to test \#2, which came after the course. However, because the difference between the pre- and post-test scores of the Experimental Group was slgniflcant only at $P<.10$, not at $P<.05$, the overall difference can not be sald to be significant with an approprlate level of confldence.

This means that a course in curricular humor had apparently little signiflcant effect on the experimental Group's over-all proficiency, and that the lack of a humor course had no apparent significant effect on the 
Control Group. Also, the course in humor apparently did not result in the Experimental Group having significantly higher scores than the control Group. Therefore, it appears that using curricular humor in this research did not significantly increase English language proficlency.

Again, there are two possible explanations. First, the explanation may be the limited exposure to humor provided by the short course. The amount of time spent per week in the humor class was less than 5 of the subject's total English class load. All of the subjects spent over 20 hours a week in a ten week course studying reading, writing, structure, TOEFL preparation, listening comprehension, and speech. The class time spent studying humor, a mere two hours, may have been too short to be of significant influence on over-all proficlency.

second, the explanation may also include the nature of the MTELP. The MTELP is generally considered a good over-all English proficlency test. However, it actually tests only reading, vocabulary, and grammar. The course in humor was not directed toward the above areas. It did provide a lot of comprehensible input, but it was not primarily a "learning" experience in the sense of Krashen's acquisition/learning dichotomy. Perhaps a different English language proflclency test 
should be used to measure proflclency whlch may reveal some more significant influence.

The third research question was "Does the use of curricular humor have a slgniflcant effect on attltudes toward Amerlcans? If so, do the different attltudes correlate positively with the Memory/recall test and the MTELP? According to the statistics, the effect of the humor course on the Experimental Group's attltudes was that they saw themselves as wanting to be less like Americans than the Control Group.

Furthermore, statistical analysis showed that having a positive attitude toward Americans (if that is what a small difference between attitudes toward Americans and attitudes toward an ldeal-self reveals) did not correlate with increased memory/recall or with Increased English proflclency. To the contrary, in regards to the Experimental Group's over-all English proficiency, the opposite was shown to be the case: the subjects' desires to be like Americans correlated negatively with proficiency. In other words, those students who appeared to have more positive attitudes towards Amerlcans (wanting to be more like them) did not achleve Improved scores on the MTELP. Thls finding suggests that integrative motivation does not necessarily result in improved language acquisition.

It seemed to the regearcher that the subjects' 
over-all attitude was very positive toward the class in humor. The attendance was always high and subjects brought non-control group frlends (The last class had close to 20 students). Subjects would often make comments such as, "I really like thls class." However, a positive attltude toward the class may not be equal to a positive attltude toward Amerlcans. Perhaps the wrong affectlve varlable was measured. Measuring the subjects' attltudes toward the class may have been a better variable to evaluate.

Here too, a couple of possible explanations may be offered. First, since a pre-test attltude survey was not taken, it is possible that the control group had a more positive attitude before the study. second, perhaps understanding American jokes and enjoying the class have nothing to do with attitudes toward Americans .

\section{CONCLUSION}

From this research, it can not be said with certainty that adding a short course in humor to an already full curriculum will result in increased memory/recall ablilty, improved proflclency, or more positive attitudes towards Americans. However, the above conclusion can not be sald with full confldence for two reasons. First, the course was very short - only five 
weeks long. This length of time may not be long enough for a humor course to have any significant effect on memory, proficiency, or attitudes.

second, despite the apparent popularity of the class, because the humor course was not a regular required course in the ESL program, but was an additional course for the subjects to take, and due to the fact that students are normally pushed to the limits of endurance without the humor course, the humor course might have been the straw that broke the camel's back. The humor course was put at the end of the student's class day, after four hours of Intensive English instruction: it may have had more of a negative, tiring effect rather than a positive, awakening one.

Despite the apparent negative correlation between this humor course and memory/recall, proflclency, and attitudes, as shown by this research, it remains for future research to discover the effects of a course in humor. The following are some suggestions for future research design:

1) The research experiment can be conducted over a longer perlod of time with larger samples.

2) Other than using a dictation test, the MTELP, and a survey, alternative measuring devices can be utllized.

3) Rather than measuring attitudes toward 
Americans, attitudes toward studying English can be measured.

4) The class can be conducted in the morning rather than in the afternoon.

5) Lastly, the class can be included in the regular curriculum as a required course rather than as an elective.

Also, in spite of the fact that a course in American Jokes was not shown, statistically speaking, to have significant effects on memory/recall, proflciency, or attitudes, since the American joke is an important and unique speech act with a cognitive process of its own, it can be considered a worthy topic of future ESL research. 


\section{REFERENCES}

Altman, Howard. 1981. What is second language teaching? In The second language classreom, James E. Alatis, Howard B. Altman (Eds.), 5-19. New York: Oxford University Press.

Balley, Kathleen M. and Marlanne Celce-Murcia. 1979. Classroom skills for ESL teachers. In Teaching English as a second or forelan language. Marlanne Celce-Murcla and Lols McIntosh (Eds.), 315 - 331. Rowley, MA: Newbury House.

Brown, H. Douglas. 1980. Princloles of language learning and teaching. Englewood Cliffs, NJ: Prentice Hall.

Clalre, Elizabeth. 1984. What's se Eunny? Rochelle Park, NJ: Eardley Publications.

Colwell, Clyde G. 1984. Applicablilty of humor in the reading/language arts curriculum. Reading world $24(2): 73-80$.

Demetrulias, Diane A. Mayer. 1982. Gags, giggles, guffaws: using cartoons in the classroom. Journal of Reading 26(1):66-69.

Elkins, Robert J. and Christian Bruggeman. 1971. Comic strips in the teaching of English as a foreign language. Paper presented to a conference on the teaching of English, Kassel, West Germany, February 5-6, 1971 .

Elzey, Freeman F. 1985. Introductory statistics: a microcomputer appraoch. Monterey: Brooks/Cole.

Gruner, Charles R. 1985. Advice to the beginning speaker on using humor: what research telis us. communication Education 34:142-147.

Hartley, Bernard and peter Viney. 1984. American streamline. New York: oxford University Press.

H111, L.A. 1977. Elementary storles for reoroduction 2. Tokyo: Oxford University Press. 
Irving, Kathy J. 1985. Cross cultural awareness and the English as a second language classroom. Theory Inte Practice 23 (oct): $138-143$.

Krashen, stephen D. and Tracy D. Terrell. 1983. The natural aporoach. oxford: Pergamon press.

Lederer, Rlchard. 1981. A primer of puns. English Journal $70(6): 32-36$.

Michigan Test of English Language Rroflciency. 1962. Ann Arbor: English Language Institute, The University of Michigan.

Monnot, Michel and Jon K1te. 1974. Pun and games: paranomasia in the ESL classroom. TESOL Quarterly $8(1): 65-71$.

Osgood, C., G. Sici and P. Tannenbaum. 1957. The measurement of meaning. Urbana: University of Illinois.

Perri, Mary Ann Geno. 1981. Just a spoonful of surgar. English Journal $70(6): 41-42$.

Pullen, J.L. 1978. A cross sectional study of the relationships between attained ESL proficiency of native Japanese speakers and their attitudes toward American English speakers. Master's research in English, Portland stae University.

Sudol, David, 1981. Dangers of classroom humor. English Journal $70(6): 26-28$.

suls, Jerry. 1983. Cognitive processes in humor appreciation. In Handbook of humor research, Paul E. McGhee and Jeffrey H. Goldstein (Eds.) $39-57$. New York:springer-Verlag.

Tavano, Rlchard D. 1986. Humor creation and appreciation as an indicator of intercultural communication effectiveness: toward a theoretical model. Master's thesis, Portland state University.

Terrell, Tracy D. 1983 The natural approach to language teaching. In Methods that work, John W. Oller, Jr. and Patricla A Rlchard-Amato (Eds.). Rowley, MA: Newbery House.

Trachtenberg, susan. 1979. Joke teling as a tool in ESL. TESOL Quarterly 13(1):89-99. 
Van Dyk, Howard. 1981. Embrace the comlc. English Journal $70(6): 48-49$.

van Els, Theo, Theo Bongaerts, Guns Extra, Charles van Os and Anne-Mieke Jannsen-van Dleten (Eds.). 1984. Apolied linguistics and the learning and teaching of foreign languages. Baltimore: Edward Arnold.

Welss, $M$. Jerry. 1981. The serlous nature of humor. English Journal $70(6): 72-74$.

Ziegler, Virginia, Gerald Boardman and Thomas $M$. Donald. 1985. Humor, leadershlp and school cllmate. clearling house $58(8): 346-348$.

Zukowski/Faust, Jean, Susan S. Johnson and Clark S. Atkinson. 1983. Between the lines. New York: Holt, Rinhart and winston. 


\section{APPENDIX A}

\section{AMERICAN HUMOR REPORT FORM}

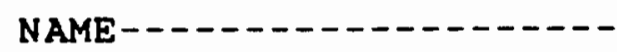

I. Practicing a Joke

Hearer's age M F

1. The Joke:

2. The result: Did it work? If not, why?

I . A joke you heard:

1. Where did you hear/find it?

2. The Joke:

3. Did you have a chance to retell this Joke? 


\section{APPENDIX B}

AMERICAN HUMOR PRE/POST EVALUATION ANSWER FORM

INSTRUCTIONS; 10 JOKES WILL BE PRESENTED. AFTER EACH JOKE IS PRESENTED, YOU WILL BE GIVEN A FEW MINUTES TO ANSWER A MULTIPLE CHOICE QUESTION AND WRITE THE JOKE. PLEASE TRY TO WRITE THE JOKE EXACTLY AS YOU HEARD IT. IF YOU CAN NOT REMEMBER THE EXACT WORDS, WRITE IT AS CLOSE AS YOU CAN.

\section{JOKE \# 1}

1) What is this foke about? (circle one)

a) work b) government c) restaurants d) good news/bad news e) people who are stupld f) marriage g)

children's Jokes $h$ ) college life () psychiatrists j) dieting $k$ ) sports

2) Write the foke: 
ARPENDIX C

SURVEY OF METAPHORICAL USAGE OF ESL LEARNERS

NAME

COUNTRY
$A G E$

SEX

\section{INSTRUCTIONS}

In the following section you will find a word or phrase at the top of each page and a series of adjective pairs separated by seven blanks.

FOR EXAMPLE :

AUTOMOBILE

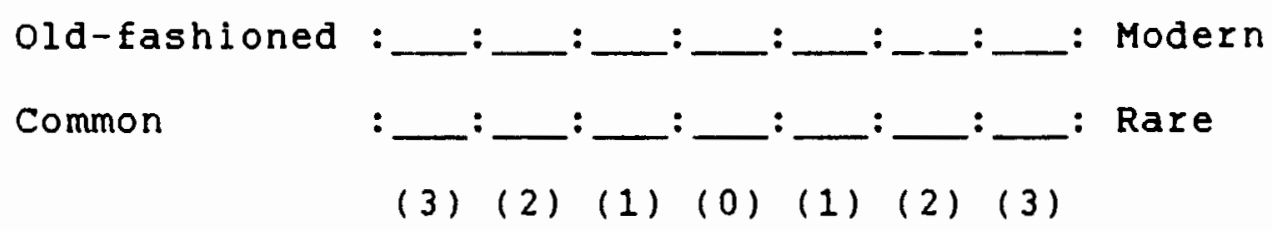

The (3) positions correspond to: quite alot, very: The (2) positions correspond to: rather, more than a little;

The (1) positions correspond to: a little, somewhat;

The $(0)$ position corresponds to: equally ballanced.

You are asked to mark one blank for each pair of adjectives to show how you rate the thing listed at the top of the page. For example, if you see "AutomoBile" as being rather modern and quite common, you will mark the blanks like this:

AUTOMOBILE

Old-Eashioned: Common

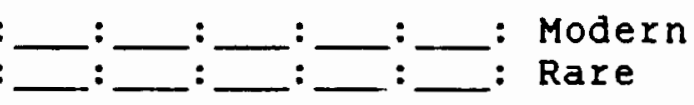


APPENDIX D

MEAN SCORES OF THE EXPERIMENTAL GROUP AND THE CONTROL GROUP

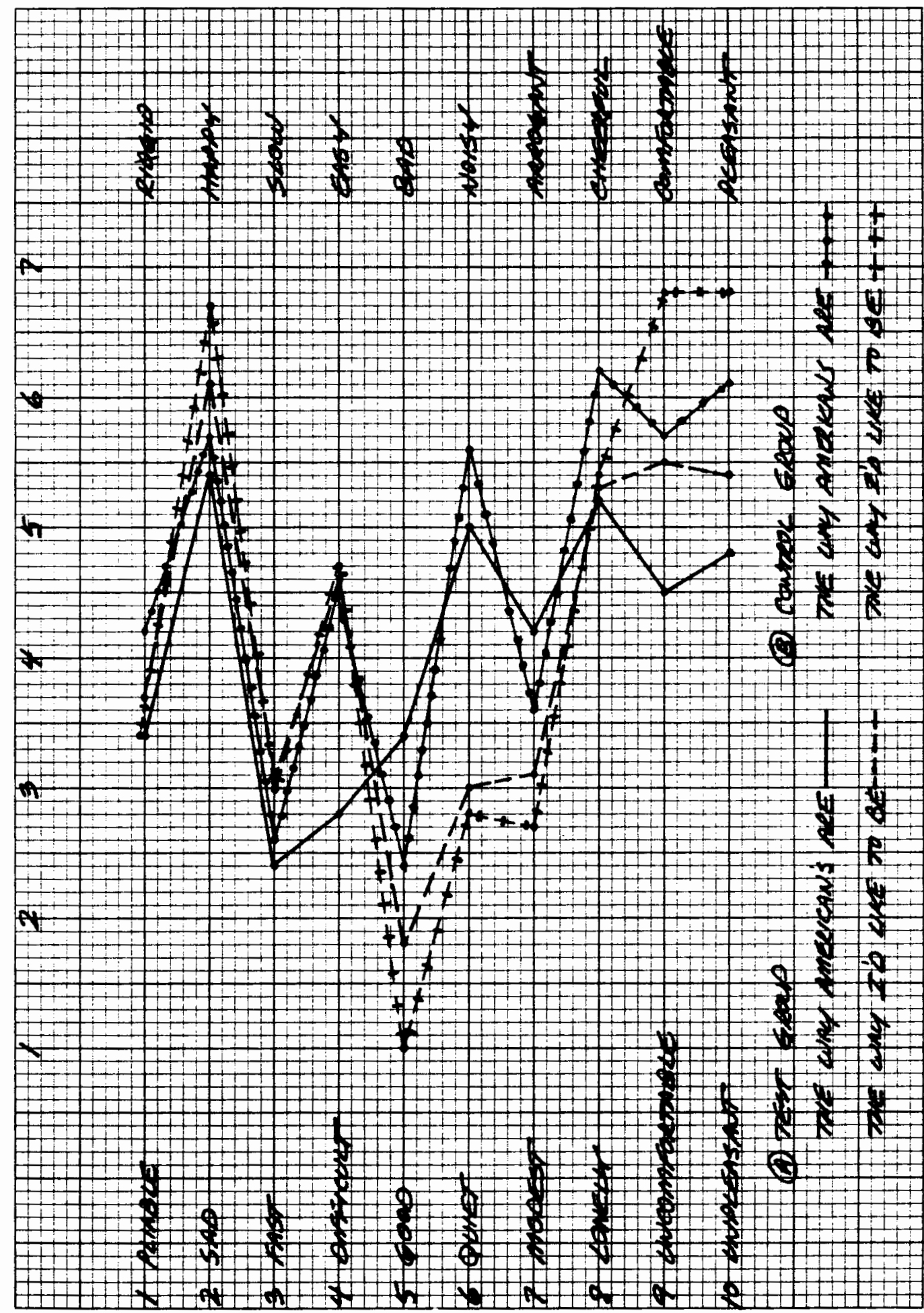


MEAN SCORES OF THE EXPERIMENTAL GROUP

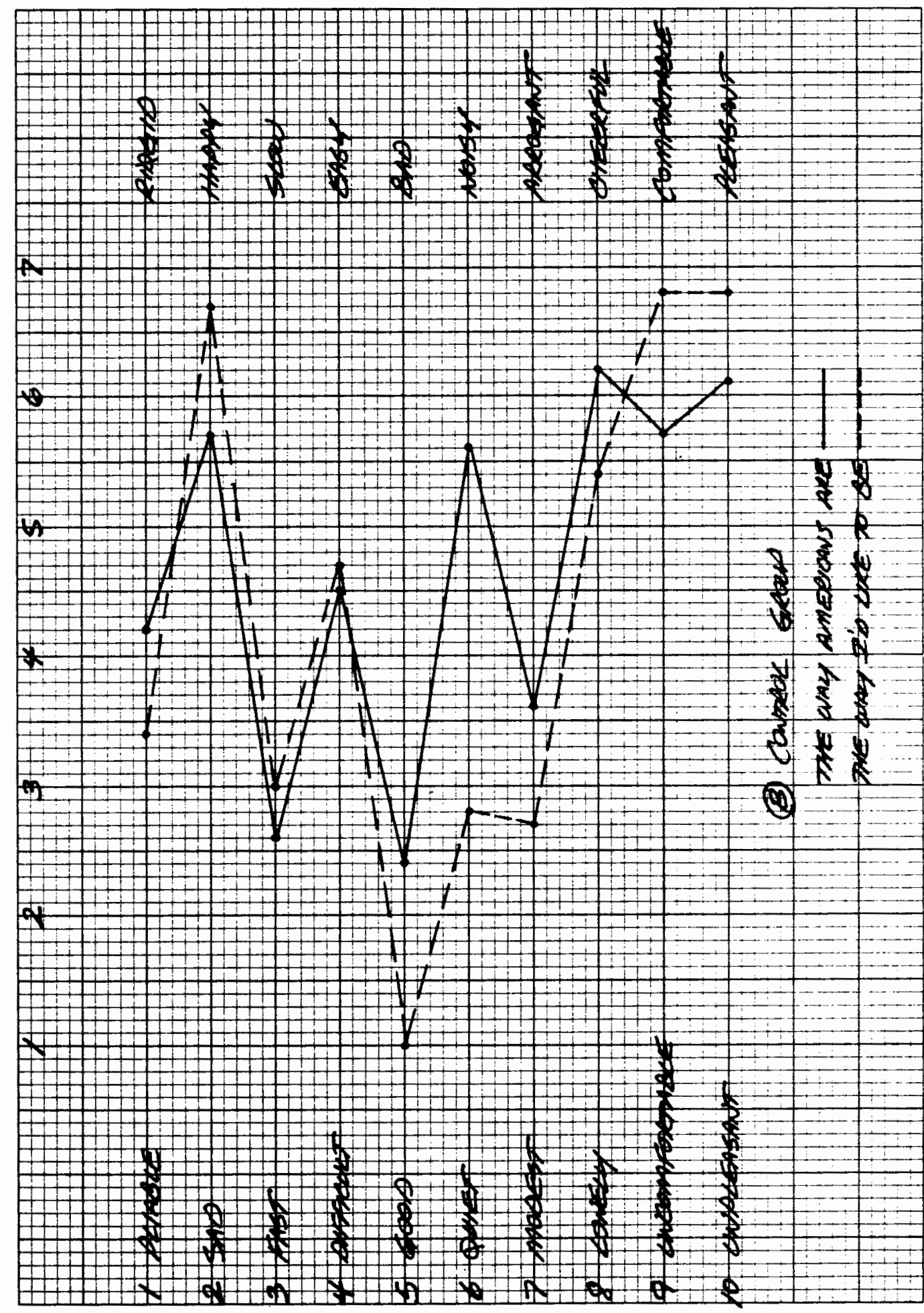


MEAN SCORES OF THE CONTROL GROUP

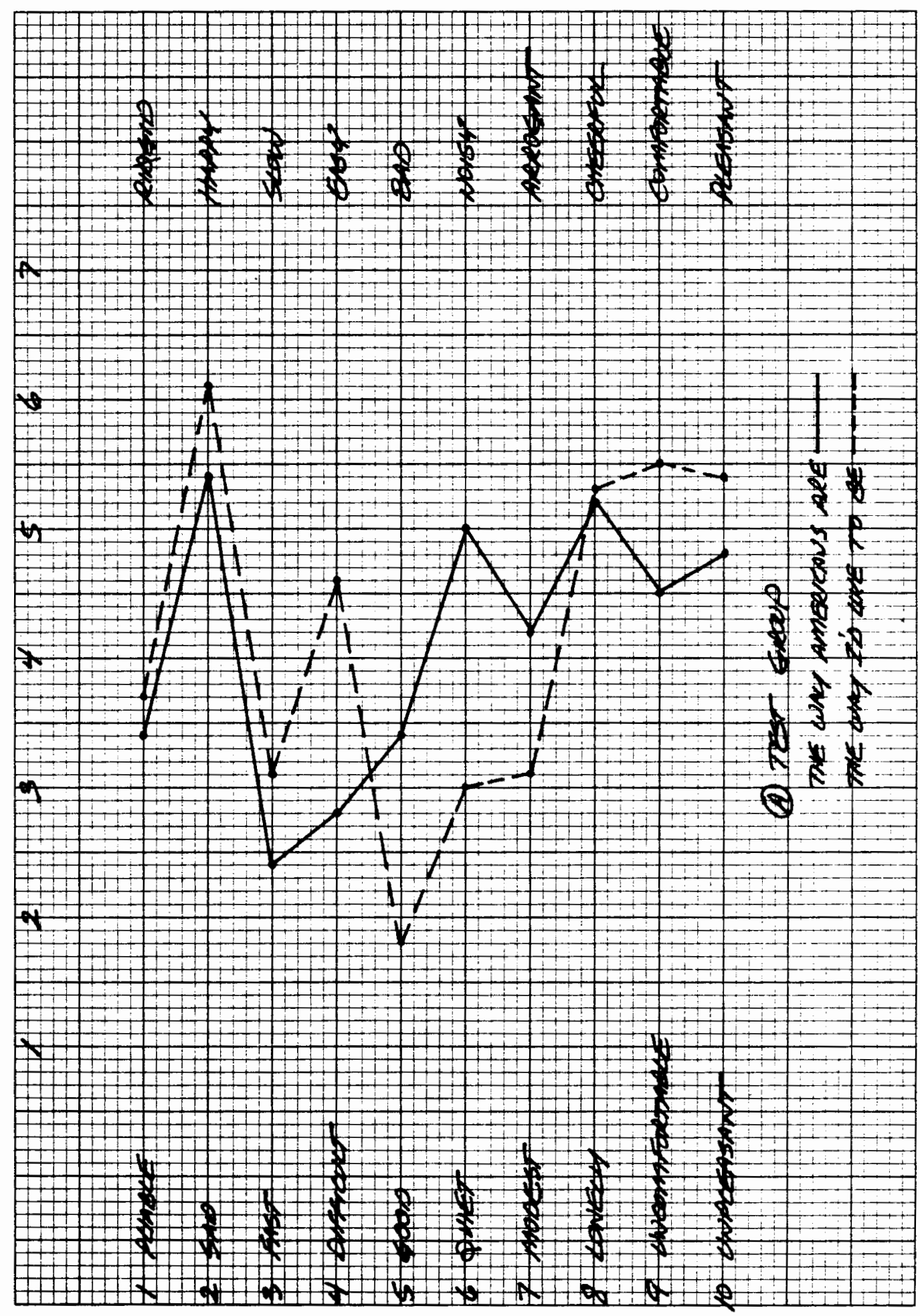




\section{APPENDIX E}

CONTROL GROUR'S MEAN SCORES ON THE ATTITUDE SURVEY

Question

$\begin{array}{rr}1 & 4.2 \\ 2 & 5.7 \\ 3 & 2.6 \\ 4 & 4.5 \\ 5 & 2.4 \\ 6 & 5.6 \\ 7 & 3.6 \\ 8 & 6.2 \\ 9 & 5.7 \\ 10 & 6.1\end{array}$
Are
The Way Americans The Way I Would Like to be
3.4
6.7
3
4.7
1
2.8
2.7
5.4
6.8
6.8

EXPERIMENTAL GROUP'S MEAN SCORES ON THE ATTITUDE SURVEY

Question

$\begin{array}{rll}1 & 3.4 & 3.7 \\ 2 & 5.4 & 6.1 \\ 3 & 2.4 & 3.1 \\ 4 & 2.8 & 4.6 \\ 5 & 3.4 & 1.8 \\ 6 & 5 & 3 \\ 7 & 4.2 & 3.1 \\ 8 & 5.2 & 5.3 \\ 9 & 4.5 & 5.5 \\ 10 & 4.8 & 5.42\end{array}$




\section{APPENDIX F}

TOTAL DIFFERENCE FOR EACH SUBJECT'S PERCIEVED DIFFERENCE - THE SUM OF THE ABSOLUTE VALUES OF THE SCORES

Contro1 Group:

$$
\begin{aligned}
& \text { subjects \#1...21 } \\
& \# 2 \ldots 8 \\
& \text { \#3...11 } \\
& 44 \ldots 12 \\
& \# 5 \ldots 21 \\
& \# 6 \ldots 23 \\
& \# 7 \ldots 10 \\
& \# 8 \ldots 15 \\
& \# 9 \ldots 18
\end{aligned}
$$

Experimental Group:

$$
\begin{aligned}
& \text { Subjects \#1...12 } \\
& \# 1 \ldots 24 \\
& \# 3 \ldots 9 \\
& 44 \ldots 16 \\
& \# 5 \ldots 16 \\
& \# 6 \ldots 18 \\
& 47 \ldots 26 \\
& \text { \#...16 } \\
& \# 9 . .18
\end{aligned}
$$


APPENDIX G

MEMORY/RECALL and PROFICIENCY SCORES

\begin{tabular}{llllll} 
& & \multicolumn{2}{l}{ Mem./Recall } & \multicolumn{2}{l}{ Proficiency } \\
Exp. Group & Pre / Post & Pre / Post \\
Subj. \#1 & 35 & 26 & 60 & 89 \\
2 & 24 & 21 & 38 & 53 \\
& 3 & 30 & 29 & 52 & 62 \\
& 4 & 38 & 45 & 74 & 86 \\
5 & 25 & 20 & 58 & 53 \\
& 6 & 20 & 14 & 62 & 62 \\
& 7 & 25 & 27 & 50 & 50 \\
& 8 & 18 & 22 & 56 & 60 \\
& 9 & 20 & 20 & 41 & - \\
& 10 & 19 & 17 & 52 & 52 \\
& 11 & 30 & 29 & & \\
Mean & & 26 & 25 & 54 & 63
\end{tabular}

Cont. Group

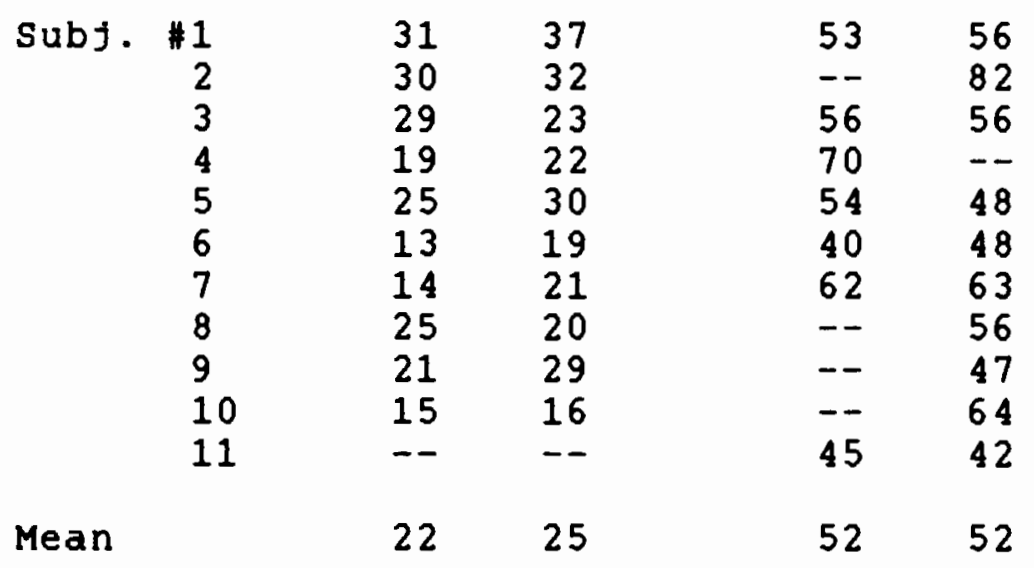

